\title{
Motivation in Public Autonomous Organizations: The Case of I.A.P.R.
}

\author{
Nikolaos Varotsis \\ Tourism Management Department, Hellenic Open University, Patras, Greece \\ Email: varotsis.nikos@ac.eap.gr
}

How to cite this paper: Varotsis, N. (2019) Motivation in Public Autonomous Organizations: The Case of I.A.P.R.. Open Journal of Business and Management, 7, 1617-1636. https://doi.org/10.4236/ojbm.2019.74112

Received: July 3, 2019

Accepted: August 12, 2019

Published: August 15, 2019

Copyright (c) 2019 by author(s) and Scientific Research Publishing Inc. This work is licensed under the Creative Commons Attribution International License (CC BY 4.0).

http://creativecommons.org/licenses/by/4.0/

\begin{abstract}
The paper demonstrates the lasting weakness of Greek public services management to motivate the Greek public employees. Especially in the case of the highly publicized independent autonomous authorities established in recent years, the lack of staff motivation cannot be attributed as a political responsibility of the Greek government but only the appointment of their top management on a case-by-case basis. On the issue of the Independent Authority of Public Revenue, a public autonomous organization with many efficiency expectations due to its independent management, the lack of substantial motivation of human resources creates questions for the achievement of its objectives. The main purpose of the paper is to highlight the I.A.P.R.'s inability to motivate its employees, by applying classical and/or modern motivation models, despite the independence of its management.
\end{abstract}

\section{Keywords}

Motivation, Public Management, Public Autonomous Organizations, Organizational Performance, I.A.P.R.

\section{Introduction}

Motivation in organizations and enterprises is one of the key elements of a modern management. Whether the fact that the overwhelming majority of workers are not happy with their work [1] or the widespread requirement for more humanitarian human resources management, motivational forces are an essential part of improving the operation of an organization or enterprise [2].

Undoubtedly, motivation is even of particular importance to public sector [3] whereon the use of financial resources is limited. Especially in Greece where fiscal adjustments focused on public wage costs and public spending [4], public employees are dominated by low morale, unable to respond to their duties due 
to lack of adequate support and low willingness to noticeably improve their work. In addition, based on the medium-term program, the prospect of incitement of public employees in Greece with non-financial means is almost one-way.

For the Greek economy, the expansion and establishment of independent authorities in the context of modernizing and reforming Greek state public administration towards new public management concept [5], besides weaning and loss of control by the central government, has fostered expectations for the implementation of new modern management policies. The establishment of such independent authorities promotes the independence of their management and their human resources management directorate, although the payroll falls within the overall public wage policy, however, it gives room for regulatory acts that differentiate the financial and non-economic benefits.

The low efficiency of public employees in Greece, both in the core of the Greek state and in the newly established, highly publicized independent authorities in the context of state reform [6], raises questions about the state of employee morale and motivation policies provided by the public administration. Key questions related to this research are whether policies to motivate human resources are being pursued in public administration, if there is knowledge of modern models of motivation and, finally, which models of motivation for civil servants are applied by the administrations of the independent authorities of the Greek public services. Especially the case of establishing the highly publicized independent authority of public revenue (I.A.P.R.), which was also a memorandum of commitment of the Greek state towards its European partners, is of even more special interest, especially with regard to the motivation of human resources.

The Independent Authority for Public Revenue (I.A.P.R.) is a Greek independent authority responsible for collecting public revenue. It is not supervised by the Greek Government, but by the Greek Parliament. The responsibilities of the I.A.P.R. include monitoring and controlling the progress of the establishment and collection of public revenue, the adoption of regulatory decisions concerning tax legislation in general and the identification of tax evasion, the trafficking phenomena and the shadow economy.

Exploring the degree of implementation of motivation models in the autonomous organization of I.A.P.R. is the main concern of this research. This research explores the human resource deeds were published by the I.A.P.R., the relation with the motivation of the human resource and the classification into motivation models. The knowledge of those motivation models, the possible degree of implementation and the finding of these motivation models applied by the human resource directorate general of I.A.P.R. are the three hypotheses of this research.

\section{I.A.P.R.}

Independent Authority for Public Revenue (I.A.P.R.) in Greece-known in 
Greek as A.A.D.E.- is the independent public revenue authority in the Greek hinterland. The main mission of I.A.P.R. is the identification, certification and collection of tax, customs and other public revenues, as it emerges by the scope of its responsibilities under Greek law. I.A.P.R. was established in 2017 [7] in line with the international standards regarding tax administration autonomy, while its objective is to implement the necessary measures for the effective and efficient operation of its tax, customs and other services in the fields of combating tax evasion, smuggling, tax fraud and the black economy.

The four main levels in the organization structure of I.A.P.R. are the organic units directly reporting to the Governor, that is the directorates general, the directorates, the special decentralized services and the regional services [8]. $\mathrm{Hu}-$ man resources management constitutes a general directorate of I.A.P.R. and enjoys operational independence, administrative and financial autonomy, while the I.A.P.R.'s management bodies are the management board and the Governor. I.A.P.R. for Greek law is a non-constitutional independent authority that enjoys extensive functional and personal independence, essentially remaining in the narrow core of the state and included in the central administration of the Greek state [9].

Taking into account the objectives of human resource management of I.A.P.R.-as published on the organization's website-the goal is to create a new human resources management system [10] with meritocracy and transparency, empowerment of employees, equal opportunities for professional development, fair evaluation and reward. The aim of human resources management is to place human resources at the helm of the transformation of I.A.P.R., into a prominent public body, thereby serving the vision to build a relationship of faith and trust with citizens. Human resources management also includes the new system of assessments from the human resources management directorate general, with key pillars, the new job description frames, performance management, earnings system and successful career paths.

\section{Models of Motivation}

The value of human resources as a key factor in superiority and success in businesses and organizations, advances their effective motivation as a primary objective of management in order to benefit from their efforts [11]. Motivation is considered to be a key component of the management, while anthropocentric approach of planning and management has been embedded in the strategy of any modern organization or business. The motivation is the desire for the degree of responsiveness that leads the behavior [12] to a goal or a certain level of performance.

The theories of motivation can be classified into two main categories. Initially the classical theories-developed by theorists Maslow, Herzberg, Alderfer, McClelland, McGregor-that investigate the nature of motivation, namely human needs, their hierarchy and means of satisfaction, focusing on the factor that 
causes the real motivation of human resource. The second category includes theories exploring the motivation process, looking for the variables that affect human motivation at work as well as the probability of correlation between them [13].

\subsection{Classical Theories of Motivation}

\subsubsection{Hierarchy of Needs}

Perhaps the most popular motivation theory is the hierarchy of needs developed by psychologist Abraham Harold Maslow. According to the hierarchy of needs [14], human behavior is motivated by specific motivations to meet specific needs. The hierarchy of needs [15] in a natural ascending order of five levels claims that only unmet needs can be a stimulus factor.

Maslow's theory evolves into a model of five levels of human needs, depicted by hierarchical different levels within a pyramid. At the lower levels, the basic human needs are ranked, first with the natural needs for survival [16] and secondly the need for security and protection [17]. The rise in the hierarchy of needs continues with the level of the need for acceptance, affection and intimacy, it continues with the level of self-esteem and is completed with the level of self-fulfillment needs. Needs ought first to be met at the lowest level of the hierarchy in order to "wake up" the longing for the next highest level. According to Maslow, a level of need does not have to be fully satisfied, but to a minimum, in order to challenge the grace for the next stage and the inception interest of dealing with a kind of behavior that meets the new need [18].

\subsubsection{Two Factor Theory}

Two factor theory of motivation developed by American psychologist Frederick Herzberg is based on the assumption that work satisfaction depends on two groups of factors [19]. Satisfaction factors (motivation) and discontent factors (hygiene) [20]. Factors of work dissatisfaction are likely to be remuneration, the environment, human work relationships [21], while factors of work satisfaction may be recognition, autonomy, personal development or job status [22]. The two groups of these factors act equally and independently in motivating the worker [23].

Two factor theory goes further along the hierarchy of needs, deepening into internal job rewards of performance at work [24]. Achieving the adequacy of hygiene is necessary to avoid employee dissatisfaction. But motivation can only be stimulated by the enrichment and quality of working conditions provided. Nevertheless, two factor theory overlooks the possibility of personal differentiation towards hygiene and motivation, adopting the positive relationship of satisfaction and performance [25].

\subsubsection{ERG Theory}

Developing Maslow's theory, Alderfer extended it further categorizing the hierarchy of needs [26] in the three categories of ERG theory: Existence needs, relatedness needs, growth needs [27]. The needs of existence include all those for the 
survival of human being by typifying the needs of survival and security. Relatedness needs relate to relationships with other people and are met through the mutual exchange of thoughts and emotions. Growth needs include the needs of self-esteem and self-fulfillment of the hierarchy of needs that affect an individual to explore the optimization of his/her personal potential in the existing environment [28].

ERG theory identified overlapping points of the three categories of needs by distinguishing that different needs can work simultaneously, bypassing the mastery of Maslow's theory. In addition, is proposed a model of fulfillment the ERG theory, according to the finding that the inability to fill a higher in the hierarchy of necessity implies doubling the effort to fill a lower hierarchical need, with the ultimate goal of the success of the highest [29].

\subsubsection{Acquired Three Needs Theory}

Based on Maslow's theory, McClelland developed the theory of three needs [30], formed on the assumption that regardless of personal, cultural and social characteristics, people have acquired needs that have been shaped by the personal experiences of their lives [31]. These needs are categorized into needs for achievement, affiliation and power, one of which is the dominant driving force of incitement [32].

The need for achievement creates attraction for challenges, search for innovation, methodical personal integrated work, taking responsibility and achieving the goal is the stronger incentive than a financial reward. The need for affiliation seeks a friendly and supportive environment, acceptance by the whole, greater personal interaction, avoidance of high risk or uncertainty, and a great deal of time to socialize and maintain relationships. The need for power is attracted by the ability to influence and control over others, to create personal prestige, to search for sovereignty and recognition, being committed, to discipline, and to be strongly motivated by the search for reputation and self-confidence [33].

\subsection{5. $X$ and $Y$ Theory}

The $\mathrm{X}$ theory and the $\mathrm{Y}$ theory are two distinct theories developed by Douglas McGregor to group managerial behavior against employees. The two conflicting models of motivation proposed by these two theories find application in the management of human resources. According to McGregor, traditional theories of human resource management are represented by $\mathrm{X}$ theory, while the $\mathrm{Y}$ theory summarizes man-centered approaches to handling workers [34].

The basic idea of $\mathrm{X}$ theory is that the employee has an innate aversion to work, is dominated by selfishness, has no ambition, maintains indifference to the objectives of the enterprise, prefers the avoidance of responsibility, and is required impetus, control, guidance, and threat to abandon the reluctance to work. In contrast, the theory $\Upsilon$ is based on the view that work is a source of satisfaction or even dissatisfaction for the worker, who can act by self-control, self-discipline, self-direction, accountability and accept the goals when it is rewarded for his de- 
sirable needs, revealing a high degree of intelligence, imagination and creativity. According to McGregor, an enterprise or organization to work effectively it is necessary to replace the direction and control of the employees with the co-operation for the integration of personality at work.

\subsection{Process Theories of Motivation}

\subsubsection{Goal-Setting Theory}

Locke and Latham's goal-setting theory, sets as a precondition for motivating employees, designing and launching a specific action plan with specific goals [35]. Certain goals can be set on specific criteria that are shaped by five features. Clarity, challenge, commitment, feedback and simplicity [36].

A determinant success factor of incitement is the acceptance of the goal. Employee involvement in setting the goal is not a guarantee of its achievement, as there is not always the same desire for participation in the goal-setting. Defining a difficult but achievable goal with employee consensus is the succinct summary of the goal-setting theory [37].

\subsubsection{Intrinsic Motivation Theory}

Thomas's intrinsic motivation theory stress the need of enriching them by inherent stimulus. While pay, additional benefits and bonuses are important, intrinsic motivation theory boosts the existence of certain inherent incentives for effective activation of the employee [38].

An extrinsic reward-possibly financial-is given by an external factor while an intrinsic reward comes from the experience gained for the successful execution of the work. The intrinsic rewards are necessary for the motivation that forms the basis of creativity. Self-management of the project by using intelligence and experience to achieve business goals leads to the innovation of creative solutions and improvisations to solve problems by choosing the best way of fulfilling the sensations of the key intrinsic rewards of meaningfulness, choice, competence and progress.

\subsubsection{Expectancy Theory}

Vroom in the theory of expectation concludes that the person's behavior results from a conscious choice among available alternatives [39], aimed at maximizing pleasure and fiction. According to the theory of expectation, an employee's performance is based on distinct factors such as personality, skills, knowledge, experience and abilities. The theory of expectation is mainly related to motivation within a working environment. When employees can make choices in their workplace they choose the activity that personally motivates them more.

According to expectancy theory the motivational force depends on the expectancy, instrumentality and valence. The theory of expectation argues that utility expresses the belief in someone's effort that will lead to performance, the instrument reflects the belief that the performance of the individual will be rewarding and the courage is the true value of rewards to the instigator [40]. This 
relationship can be mapped to the model Motivational Force $(M F)=$ Expectancy $\times$ Instrumentality $\times$ Valence, that represents the direction of the incentives when the behavior occurs [41]. Employees prefer to get the most out of their work with the least effort. Individual factors play an important role in the objectives to be achieved and in the behavior of workers. Individual effort, performance and motivation are always intertwined. The positive correlation between effort and performance [42] has the effect of motivating workers [43].

\subsubsection{Equity Theory}

Adams' equity theory calls for a parity [44] between inputs (hard work, skills level, ability level, acceptance, enthusiasm, etc.) and employee performance (wages, benefits, immaterial rewards such as recognition, etc.), focusing on finding a fair balance which resolves the dispute over whether the allocation of resources is fair to an organization [45]. The equity theory developed by J. Stacy Adams, overcomes pay as the key single reward factor, contributing to the motivation of the fairness factor by comparing a worker's pay with someone doing similar work.

The theory of equity focuses on the fact that people choose a level of effort in their work that they think is fair or equivalent [46]. The concept of the theory encourages workers to reward them on a fair basis, since the latter are interested in their remuneration on a comparative basis with those who do the same job and not on an absolute basis, that is, the amount of their rewards [47]. According to this theory, unreasonable reward causes workers to resent, reduce effort or even give up work. Feeling of failing to receive a fair reward is likely to give rise to dissatisfaction, while comparing with similar pay causes discouragement from effort, re-emphasizing the importance of social and interpersonal comparability.

\subsubsection{Theory of the Expectation Model}

Porter and Lawler based on Victor Vroom's theory of expectation, led to the conclusion that a person's motivation to complete a job is mainly influenced by the reward he is expected to receive to complete the project [48]. In addition, they distinguished the reward to endogenous and exogenous. The endogenous reward consists of positive feelings from the experiences gained from the completion of work, e.g. satisfaction, sense of achievement. External rewards are rewards from the outside environment, such as financial rewards, wage increases, extra benefits, extra bonus [49].

In fact, theory concludes that motivation does not amount to satisfaction or performance. A multifactorial model is suggested that can explain the relationship of satisfaction and efficiency [50]. The critical point of the model is that effort or motivation does not directly lead to performance. In essence, it is rooted in the skills, characteristics and perceptions of the roles. The core elements of the proposed motivation model include the effort spent to achieve the goal, the performance related to the skills and the satisfaction that depends on the degree of completeness achieved by the rewards, at the level of the final rewards. Ulti- 
mately, motivation to improve performance is related to the subjective appreciation of real rewards as well as to the assessment of the required effort that will lead to estimated internal and external returns [51].

\subsubsection{Reinforcement Theory}

Reinforcement theory [52] is based on the concept of the law of effect [53]. Consequently, the behavior leading to positive consequences tends to be repeated, while the one that has negative consequences tends to be overcome [54]. Skinner's reinforcement theory is based on the two types of human behavior, the response to a direct stimulus and the functional one taking place in the absence of any stimulus. Two are the main elements of the theory of functional addiction [55]. Behavior (education) and environment.

Reinforcement motivation theory aims to achieve the desired level of incentives [56] among employees through reinforcement, punishment and elimination [57]. The amplification approach, which may be positive and negative [58], is used to enhance the desired behavior [59]. Punishment acts as a deterrent to unwanted employee behavior. Elimination refers to reducing the likelihood of unwanted behavior [60].

\section{Modern Models of Motivation}

The shortcomings of classical theories of motivation, led to the development of more comprehensive contemporary motivational modern theories. Despite the familiarization and understanding of classical motivation theories-which have worked as a source of inspiration and commitment to motivating staff-some of them have not empirically proven to function effectively [61]. The combination of early classical and modern motivation theories can help understand, analyze and influence human behavior in organizations and enterprises.

Modern theories of motivation have been developed over the past few years and aim to study in more detail the omens or factors that drive human behavior to be motivated [62]. Modern motivation models take into account past classical motivation theories in order to propose a modern implementation model in daily work. These modern models are more man-centered focusing on the deeper desires of the human factor and fading the economic motivating factor as a key factor of empowerment in motivating work.

\subsection{Self-Determination Theory}

The theory of self-determination was developed by Deci and Ryan, which, based on Porter and Lawler's expectation model, focuses on internal motivation [63]. According to the theory of self-determination, internal motivation is determined by the desire of a worker to engage in an activity either because he enjoys it or because he finds it really interesting. The concept of autonomous and dependent motivation takes place at the heart of the theory of self-determination. Self-motivation is an internal motivation and translates into the desire to perform the job [64]. Contrary to the assumption that the main motivation for the 
job is a motivating factor and at the same time an obligation on the part of the worker to perform a task [65].

The theory focuses on three internal factors that need to be strengthened in order to achieve prosperity [66]. The adequacy of controlling the outcome, the relevance of interconnection and interest to others, and the autonomy of functioning autonomously and in harmony with oneself. Each factor needs to be induced differently at different times. The theory of self-determination focuses on the employee's inner mood to develop relationships with his colleagues and the wider social community he belongs to. The self-determination theory is investigating a wide range of factors such as gender, culture, age and socio-economic status. Prominently explores the factors that trigger the person's behavior in order to turn it into reality [67]. Human perceptions, cognitive functions, emotions, human needs are the sources of any results.

\subsection{Self-Efficacy Theory}

The theory of self-efficacy [68] is based on the belief that human is able to perform a specific task or achieve a specific goal [69]. The theory was developed by Bandura, which defines it as a personal perception of how effectively an individual can perform the process to meet a future goal [70]. Every person has the ability to use and strengthen his/her self-efficacy. Efficacy-related beliefs determine the way of thinking, motivation and behavior, reproducing different results through four processes. Self-efficacy come from these four sources of efficacy beliefs [71].

The first basic source of self-efficacy arises from personal master experience. Overcoming obstacles through personal effort and perseverance promotes a sense of self-efficacy, boosting self-confidence [72]. The second source of self-efficacy is the experiences and, in particular, the most successful ones, which creates the belief that the observer has the skills to succeed. The third source is the social influence from influential people, which is able to convince that the appropriate activities are available when trying to achieve a goal. The emotional state is the fourth determining source of beliefs [73]. Positive emotions reinforce self-efficacy while a bad emotional state or condition (anxiety, depression, etc.) undermines self-confidence. According to the theory, virtual experience, id est the visualization of a successful self, can enhance self-efficacy.

\subsection{Job Characteristics Theory}

Hackman and Oldham's job characteristics theory aims at the proper design of the job and is based on the belief that work itself can be an incentive [74]. Hackman \& Oldham developed a model of motivation based on five features (description, importance, skills, autonomy, feedback) that impact on job results. According to the theory it is essential to highlight the key features of work that can affect attitudes and behaviors of workers, and in this case the definition of working conditions that maximize this influence [75]. 
The Hackman and Oldham model focuses on three psychological situations around which emerge the five key features of the work [76]. The first comes from the experience gained from the performance of the work, the second from the sense of autonomy and the third from the gained knowledge of the results. The simultaneous existence of all three situations can cover the need to achieve and motivate the work process.

\subsection{Nudge Theory}

Nudge theory [77] is an introducing motivation theory developed by behavioral scientists Thaler [78] and Sunstein [79] based on Kahneman's [80] early works and the formation in cybernetics by Wilk [81]. The theory also known as "the art of nudge" is based on any aspect of intervention that changes a person's behavior in a predictable way without excluding available options or changing financial incentives [82].

The proposed corrections need to be painless at no cost and are not mandates or bans. In fact, finding beneficial intervention is an influence on work behavior [83]. The primary purpose of nudge theory in the workplace is to achieve zero accidents from the working culture and to provide nudge interventions in the communication that motivates the achievement of the work project [84].

\section{Method}

This research was accomplished with the quantitative method of data analysis. The data were collected from the official information system of the human resources directorate division of the Independent Authority for Public Revenue (I.A.P.R.) in Greece. The key features that helped in choosing the data analysis methodology is the easy access to all the deeds and decisions of the personnel and administration management concerning the staff of the I.A.P.R., the validity of the analysis as the information system contains all the decisions regarding the personnel management, and the objectivity of the human resources management policy of the organization.

\subsection{Data}

In this study, the data comprised of regulatory circulars and other rulings of the human resource directorate general of I.A.P.R. since the date of the organization's establishment on 1st January 2017. Primary data were collected by use of the publicity information system "diavgeia" of Greek public services. The study used SPSS 20.0 to analyze data collected.

The digital platform "diavgeia" was established in 2010 [85] and aims at maximizing the publicity of government policy and administrative activity, ensuring transparency and accountability by public authorities. Since October 2010, all decisions of governmental and administrative acts have been posted at a point on the Internet, with a special exception being given to national defense and sensitive personal data. 
Under the responsibility of the institution that issued it, the act is described as "on the Internet" on the draft of its document. After the publication is completed, it is registered electronically (the file must be in pdf format) in the special application of laws and operations registration available centrally by the IT development department of the Ministry of administrative reform and e-Government. Upon completion of the posting, each institution act is digitally signed by the information system and acquires a unique web posting number. The posted service document other than those published in the government gazette prevails over all other versions of the act.

\subsection{Procedure}

The data were systematically collected from the digital platform "diavgeia" through recording of the published decisions of the Human Resources Directorate of I.A.P.R. The key features that helped in choosing the data collection is the obligation of the Human Resources Directorate of I.A.P.R. to publish the total decisions and deeds that affect the human resources of the organization, the high accuracy of data collection at a relatively low cost, and the easy-to-use process of collecting actions affecting remuneration and motivation policies.

Classification of decisions was made in accordance with the contents of the deeds and other acts of the Human Resources Directorate of I.A.P.R. as well as the recipients of these decisions. Simple search is done by inserting a keyword in the search field at the top of the homepage "diavgeia.gov.gr". In the case of searching for a specific public body's posts, the user chooses from the right-hand side of the site the choice of the public operator that interests him/her-e.g. I.A.P.R. Accordingly, it may choose the address of a specific public body, public organization or independent/autonomous public authority/organization e.g. human resources directorate general of I.A.P.R.

\section{Results}

This research was accomplished with the quantitative method of data analysis. The collection of data was carried out by an information subsystem for the publication of administrative acts of the public services "diavgeia". Since the establishment of the I.A.P.R. organization, the human resources directorate general of I.A.P.R. has published a total of 750 human resource deeds. Most of these relate to personnel change decisions, such as a change in wage earning pay scales due to maturity, or regulatory decisions on metathesis or/and retirement of employees.

The results are aimed at responding to the key concern of this research, the degree of application of motivation models in the case of the Greek public autonomous organization of I.A.P.R. More specifically, the three hypotheses examined are the possibility of knowing motivational models, the degree of implementation of specific motivation models in human resource management, and the inventory of the finally applied motivation models by the human re- 
sources directorate general of I.A.P.R.

The results start with a general overview of the general decisions of the I.A.P.R. Directorate-General for Human Resources, they continue by separating them into deeds to motivate staff and decisions that are aimed at procedural issues and are completed by classifying these actions to motivate human resources based on their content in a particular motivation model. A summary of the decisions of the human resource directorate general of I.A.P.R. is presented in Table 1.

Subsequently, an analysis of the contents of the human resource acts, deeds and operations in order to classify them into those aimed in directly or indirectly to motivate the employees (e.g. salary increases, additional benefits, change in the job) and those that relate to other staff procedures (e.g. recruitment, retirement, circulars, etc.) (Table 2).

Finally, acts, deeds and operations relating to the direct or indirect motivation of staff were classified by type of provision in monetary or non-monetary and by purpose in one of the above-mentioned models of motivation of the human resources (Table 3).

The basic key criterion for classifying human resources operations in the hierarchy of needs was the basic monetary wage (physical needs), while for the other models the criterion of whether the pay is related to the provision or reward

Table 1. Summary of human resources management directorate deeds. Source: I.A.P.R.'s Diavgia, (2019).

\begin{tabular}{cccc}
\hline & Category & Thematic & Host \\
\hline 1. & Registry changes & Public Administration & 38 \\
2. & Appointments & Staffing & 26 \\
3. & Regulation deeds & Employment and work & 30 \\
4. & Other deeds & Fiscal, Restructuring & 656 \\
\hline
\end{tabular}

Table 2. Distinction between motivational and other actions. Source: I.A.P.R.'s Diavgia, (2019).

\begin{tabular}{rccc}
\hline & Purpose & Content & Host \\
\hline 1. & Motivation & Provision & 573 \\
2. & Procedures & Order & 177 \\
\hline
\end{tabular}

Table 3. Classification of HR deeds on models of employee motivation. Source: I.A.P.R.'s Diavgia, (2019).

\begin{tabular}{cccc}
\hline & Motivation Model & Payroll & Non-payroll \\
\hline 1. & Hierarchy of needs (Maslow) & 567 & - \\
2. & Two factor (Hertzberg) & 3 & - \\
3. & Goal setting (Locke) & 2 & - \\
4. & Intrinsic motivation (Thomas) & - & 1 \\
\hline
\end{tabular}


of the staff (e.g. achievement target reward, health security, etc.). The review of the overall outcome has as its main conclusion the use of only one non-monetary mobilization of human resources and the limitation on the application of only four motivation models.

\section{Discussion}

Employee's motivation models not arise from the analysis of the results being one of the priorities of the I.A.P.R. Human Resources management. As a consideration, the human resource management operations of I.A.P.R. are limited to wage ripening and some wage improvements, without a clear purpose or expected benefits being improved in employee performance. Wage maturity is the implementation of wage law for civil servants and is not in fact associated with any spontaneous or targeted decision to motivate the employees of the organization.

Possibly the human resource directorate general of I.A.P.R. does not have knowledge of employee motivation models. The absence of a staff management decision that aims, for example, in equitable distribution of earnings or even in the expectation of something similar, shows ignorance of incitement with a motivation model of the employees of the organization. Persistence of wage maturity for all staff on the basis of the legislation in force is essentially not a mean of motivation since it is not related to any reward, improvement or restructuring of employees' emoluments.

The hierarchy of needs theory and in a few cases the two factors theory, the goal setting theory and the intrinsic motivation theory have been used fragmentarily for the motivation of the staff, while the other models of motivation do not appear to be sources for the implementation of policies motivating the I.A.P.R.'s human resources. Ignorance in the implementation of policies and decisions of I.A.P.R.'s Directorate-General for Human Resources using timeless models of motivation such as the equity theory, expectancy theory, $\mathrm{x}$ and $\mathrm{y}$ theory or/and reinforcement theory, seems to reveal a management profile adhered to outdated management standards.

Modern motivation models [86] do not appear to be in knowledgeable since the human resources directorate general of I.A.P.R. While the implementation of modern human resource motivation models does not require additional financial resources, it does not seem to find any application in the case of I.A.P.R. despite the lack of additives available financial resources to raise staff salaries [87]. Motivation with features such as autonomy, feedback, or/and nudges are unknown tools in the effort to improve efficiency by focusing on the humanitarian factor of human relations at work.

The one-sided use of minimal available financial resources to motivate human resources is based on the lower level of the Maslow's hierarchy of needs pyramid, ignoring that motivation can only be achieved at higher levels of satisfying needs. But even if the meager additional financial benefits to the employees of 
I.A.P.R. satisfy the lower hierarchical rank of the Maslow's pyramid, possibly there is ignorance in the effective implementation of the model in that only fulfillment of needs at the lower level of hierarchy can awaken the craving for satisfaction at higher levels of needs.

Timeless employees' demands for wage increases in Greece [88] show that any incentive measures of an economic nature are spent without achieving their purpose. On the other hand, the influences of new public management policies [89] are exhausted in the issuance of new I.A.P.R.'s job description regulation [90], without taking into account the personal characteristics of the employees. In any case, the publication of a job descriptions' regulation does not meet on the application of a motivation model based on the job description theory.

To sum up, the implementation of motivation models in the public service of the Greek government in the case of I.A.P.R. is not part of the human resource management mix of the organization. Limiting I.A.P.R.'s personnel management policies to meagre wage developments, highlight a scanty mix of motivation for human resources. The margins for implementing policies that motivate staff are broad insofar as there is a willingness to implement them by the I.A.P.R.'s top management.

\section{Conclusions}

This research showed that almost all of the I.A.P.R.'s public employees' motivation policies are confined to the hierarchy of needs theory, while there is a total ignorance of the existence of modern models of motivation for human resources. The results of the foregoing analysis supported the hypothesis that the I.A.P.R.'s management is unaware of most of the motivation models of human resource.

As regards hypothesis 1 concerned, the management of I.A.P.R. does not seem to have knowledge of both early and modern models of motivation. From the classical models of motivation of human resource, there is mainly knowledge of the Maslow's hierarchy model and little, of the Herzberg's two factors model. There is little knowledge of the process models of motivation, and there is no knowledge of the modern models of motivation of human resource.

For hypothesis 2, the degree of implementation of staff motivation models, though one-sided-limited to poor financial incentives-is noticeably perceptible from the human resource directorate general of I.A.P.R. The main conclusion resulting from the decisions of the human resource directorate general of I.A.P.R. is that an effort is being made through the salary's maturity of experienced staff's pay; however, probably because of the tax system, even this poor economic agent does not have a real effect on human resources pay.

The results exploring hypothesis 3 on models of motivation that is ultimately implemented by the I.A.P.R.'s Directorate-General for Human Resources, conclude that it is basically confined to the overwhelming majority of deeds in the implementation of the Maslow's hierarchy of needs model. As it emerged from 
the classification of decisions of the Human Resources Division, almost all of them are incorporated to the lower hierarchical levels of the Maslow's pyramid. Consequently, from the classical theories of motivation applied, the overwhelming majority of the I.A.P.R.'s Directorate-General for Human Resources decisions aimed at motivating staff, are based on the concept of Maslow's hierarchy of needs model, with only few exceptions to the application of Herzberg's model, Locke's goal-setting model and Thomas's intrinsic motivation model. None of the modern motivation models has been implemented so far by the I.A.P.R.'s Directorate-General for Human Resources.

This paper set out to explore the motivation of autonomous Greek public organizations in the case of I.A.P.R. After initially presenting the concept of autonomous Greek public organizations and the Independent Authority for Public Revenue (I.A.P.R.), then presented the human motivation models that the human resources management of an organization can use to motivate its human resources. The presentation of the results concluded that in the case of I.A.P.R. there is limited knowledge of the models of motivation of human resources, the degree of motivation of the staff is extremely low and when human resource management chooses the motivation to stimulate human resources, it is unilaterally provided with scanty financial benefits aimed at motivating the needs of the lower levels of the Maslow's hierarchy of needs theory.

\section{Conflicts of Interest}

The author declares no conflicts of interest regarding the publication of this paper.

\section{References}

[1] Wright, B.E. (2001) Public-Sector Work Motivation: A Review of the Current Literature and a Revised Conceptual Model. Journal Public Administration Research and Theory, 11, 559-586. https://doi.org/10.1093/oxfordjournals.jpart.a003515

[2] Belle, N. (2012) Experimental Evidence on the Relationship between Public Service Motivation and Job Performance. Public Administration Review, 73, 143-153. https://doi.org/10.1111/j.1540-6210.2012.02621.x

[3] Manolopoulos, D. (2007) An Evaluation of Employee Motivation in the Public Sector in Greece. Employee Relations, 30, 63-85. https://doi.org/10.1108/01425450810835428

[4] Karantinos, D. (2013) The Social and Employment Situation in Greece. European Council, 2013. European Union, Brussels.

[5] Lampropoulou, M. and Oikonomou, G. (2018) Theoretical Models of Public Administration and Patterns of State Reform in Greece. International Review of Administrative Sciences, 84, 101-121. https://doi.org/10.1177/0020852315611219

[6] Spanou, C. (2008) State Reform in Greece: Responding to Old and New Challenges. International Journal of Public Sector Management, 21, 150-173. https://doi.org/10.1108/09513550810855645

[7] Greek Tax Code (2016) Urgent Provisions for Implementing the Agreement on Budgetary Objectives and Structural Reforms and Other Provisions. Law, 4389/2016. 
The National Printing House, Athens.

[8] Greek Tax Code (2017) Organization of Independent Authority for Public Revenue. Law, FEK B 968/2017. The National Printing House, Athens.

[9] Greek Tax Code (2014) Principles of Financial Management and Supervision-Public Accounting and Other Provisions. Law, 4270/2014. The National Printing House, Athens.

[10] Independent Authority for Public Revenue (2019) Human Resource Management. Independent Authority for Public Revenue Press, Athens.

https://www.aade.gr/dl assets/vat/HRMS

[11] Colquitt, J.A., LePine, J.A. and Wesson, M.J. (2014) Organizational Behavior. McGraw Hill, New York.

[12] Weingart, L.R. and Jehn, K.A. (2009) Manage Intra-Team Conflict through Collaboration. In: Locke, E., Ed., Handbook of Principles of Organizational Behavior. Indispensable Knowledge for Evidence-Based Management, John Wiley and Songs, Ltd., West Sussex, 327-346.

[13] Scandura, T.A. (2019) Essentials of Organizational Behavior: An Evidence-Based Approach. SAGE Publications, Inc., Los Angeles.

[14] Maslow, A.H. (1954) Motivation and Personality. Harper and Row Publishers, Inc., New York.

[15] Ventegodt, S., Merrick, J. and Andersen, N.J. (2003) Quality of Life Theory II. Maslow Revisited. The Scientific World Journal, 3, 1050-1057. https://doi.org/10.1100/tsw.2003.84

[16] Benson, S.G. and Dundins, S.P. (2003) Understanding and Motivating Health Care Employees: Integrating Maslow's Hierarchy of Needs, Training, and Technology. Journal of Nursing Management, 11, 315-320. https://doi.org/10.1046/j.1365-2834.2003.00409.x

[17] Mathes, E.W. (1980) Maslow's Hierarchy of Needs as a Guide for Living. Journal of Humanistic Psychology, 20, 321-333.

[18] Koltko-Rivera, M.E. (2010) Rediscovering the Later Version of Maslow's Hierarchy of Needs: Self-Transcendence and Opportunities for Theory, Research, and Unification. Review of General Psychology, 10, 302-317. https://doi.org/10.1037/1089-2680.10.4.302

[19] Herzberg, F., Mausner, B. and Snyderman, B. (1959) The Motivation to Work. Wiley, New York.

[20] Herzberg, F. (1987) One More Time: How Do You Motivate Employees? Harvard Business Review, 65, 109-120.

[21] Zhang, P. and Von Dran, G.M.S. (2000) Satisfiers and Dissatisfiers: A Two-Factor Model for Website Design and Evaluation. Journal of the American Society for Information Science, 51, 1253-1268. https://doi.org/10.1002/1097-4571(2000)9999:9999<::AID-ASI1039>3.0.CO;2-O

[22] Bassett-Jones, N. and Lloyd, G.C. (2005) Does Herzberg's Motivation Theory Have Staying Power? Journal of Management Development, 24, 929-943. https://doi.org/10.1108/02621710510627064

[23] Lundberg, C., Gudmundson, A. and Andersson, T.D. (2009) Herzberg's Two-Factor Theory of Work Motivation Tested Empirically on Seasonal Workers in Hospitality and Tourism. Tourism Management, 30, 890-899. https://doi.org/10.1016/j.tourman.2008.12.003

[24] Kalleberg, A.L. (1977) Work Values and Job Rewards: A Theory of Job Satisfaction. 
American Sociological Review, 42, 124-143. https://doi.org/10.2307/2117735

[25] House, R.J. and Wigdor, L.A. (1967) Herzberg's Dual-Factor Theory of Job Satisfaction and Motivation: A Review of the Evidence and a Criticism. Personnel Psychology, 20, 369-390. https://doi.org/10.1111/j.1744-6570.1967.tb02440.x

[26] Schneider, B. and Alderfer, C.P. (1973) Three Studies of Measures of Need Satisfaction in Organizations. Administrative Science Quarterly, 18, 489-505. https://doi.org/10.2307/2392201

[27] Alderfer, C.P. (1969) An Empirical Test of a New Theory of Human Needs. Organizational Behavior and Human Performance, 4, 142-175.

https://doi.org/10.1016/0030-5073(69)90004-X

[28] Ferreira, T.S. (2017) Motivational Factors in Sales Team Management and Their Influence on Individual Performance. Tourism and Management Studies, 13, 560-565. https://doi.org/10.18089/tms.2017.13108

[29] Alderfer, C.P. (2011) The Practice of Organizational Diagnosis: Theory and Methods. Oxford University Press, New York.

[30] McClelland, D.C. (1985) How Motives, Skills and Values Determine What People Do. American Psychologist, 40, 812-825. https://doi.org/10.1037/0003-066X.40.7.812

[31] McClelland, D.C. (1965) Toward a Theory of Motive Acquisition. American Psychologist, 40, 812-825. https://doi.org/10.1037/h0022225

[32] Daft, R.L. (2007) Management. Thompson South-Western, Mason.

[33] McClelland, D.C. (1988) Human Motivation. University Press, Cambridge. https://doi.org/10.1017/CBO9781139878289

[34] Lawter, L., Kopelman, R.E. and Prottas, D.J. (2015) McGregor's Theory x/y and Job Performance: A Multilevel, Multi-Source Analysis. Journal of Managerial Issues, 27, 84-101.

[35] Lock, E. (1968) Towards a Theory of Task Performance and Incentives. Organizational Behavior and Human Performance, 3, 157-189. https://doi.org/10.1016/0030-5073(68)90004-4

[36] Latham, G.P. and Locke, E. (1991) Self-Regulation through Goal Setting. Organizational Behavior and Human Decision Performances, 50, 212-247. https://doi.org/10.1016/0749-5978(91)90021-K

[37] Locke, E. and Latham, G. (2004) What Should We Do about Motivation Theory? Six Recommendations for the Twenty-First Century. Academy of Management Review, 29, 388-403. https://doi.org/10.5465/amr.2004.13670974

[38] Thomas, K.W. (2009) Intrinsic Motivation at Work. Berrett-Koehler Publishers, Inc., San Francisco.

[39] Vroom, V.H. (1964) Work and Motivation. Wiley, New York.

[40] Greenberg, J. and Baron, R.A. (2008) Behavior in Organizations. Pearson, Hoboken, 269-274.

[41] Eerde, W.E. and Thierry, H. (1996) Vroom's Expectancy Models and Work-Related Criteria: A Meta-Analysis. Journal of Applied Psychology, 81, 575-586. https://doi.org/10.1037/0021-9010.81.5.575

[42] Barba-Sanchez, V. and Atienza-Sahuquillo, C. (2017) Entrepreneurial Motivation and Self-Employment: Evidence from Expectancy Theory. International Entrepreneurship and Management Journal, 13, 1097-1115.

https://doi.org/10.1007/s11365-017-0441-z 
[43] Lunenburg, F.C. (2011) Expectancy Theory of Motivation: Motivating by Altering Expectations. International Journal of Management Business, and Administration, 15, 1-9.

[44] Adams, J.S. (1965) Inequity in Social Exchanges. Advances in Experimental Social Psychology, 2, 267-300. https://doi.org/10.1016/S0065-2601(08)60108-2

[45] Adams, J.S. and Freedman, S. (1976) Equity Theory Revisited: Comments and Annotated Bibliography. Advances in Experimental Social Psychology, 9, 43-90. https://doi.org/10.1016/S0065-2601(08)60058-1

[46] Huseman, R.C., Hatfield, J.D. and Miles, E.W. (1987) A New Perspective on Equity Theory: The Equity Sensitivity Construct. Academy of Management Review, 12, 222-234. https://doi.org/10.5465/amr.1987.4307799

[47] Butler, M. and Rose, E. (2011) Introduction to Organizational Development. CIPD, London.

[48] Porter, W. and Lawler, E. (1968) Managerial Attitudes. Irwin, New York.

[49] Lawler, E.E. and Suttle, J.L. (1973) Expectancy Theory and Job Behavior. Organizational Behavior and Human Performance, 9, 482-503. https://doi.org/10.1016/0030-5073(73)90066-4

[50] Lawler, E.E. and Porter, L.W. (1967) Antecedent Attitudes of Effective Managerial Performance. Organizational Behavior and Human Performance, 2, 122-142. https://doi.org/10.1016/0030-5073(67)90026-8

[51] Edwards, N.A. and Augustyn, J.C.D. (1986) A Validation Study of Lawler's Expectancy Model on Low-Level Rural Black Workers. Journal of Industrial Psychology, 12, 17-21. https://doi.org/10.4102/sajip.v12i1.455

[52] Gray, P. and Bjorklund, D.F. (2014) Psychology. Worth Publishers, New York.

[53] Thorndike, E. (1898) Some Experiments on Animal Intelligence. Science, 7, 818-824. https://doi.org/10.1126/science.7.181.818

[54] Skinner, B.F. (1974) About Behaviourism. J. Cape, New York.

[55] Skinner, B.F. (1971) Beyond Freedom and Dignity. A.A. Knopf, Inc., New York.

[56] Berridge, K.C. (2001) Reward Learning: Reinforcement, Incentives, and Expectations. The Psychology of Learning and Motivation, 40, 223-278.

https://doi.org/10.1016/S0079-7421(00)80022-5

[57] Villere, M.F. and Hartman, S.S. (1991) Reinforcement Theory: A Practical Tool. Leadership and Organization Development Journal, 12, 27-31. https://doi.org/10.1108/01437739110138039

[58] Carvalho, J.P. and Hopko, D.R. (2011) Behavioral Theory of Depression: Reinforcement as a Mediating Variable between Avoidance and Depression. Journal of Behavior Therapy and Experimental Psychiatry, 42, 154-162. https://doi.org/10.1016/j.jbtep.2010.10.001

[59] Luthans, F. and Stajkovic, A.D. (1999) Reinforce for Performance: The Need to Go beyond Pay and Even Rewards. Academy of Management Executive, 13, 49-57. https://doi.org/10.5465/ame.1999.1899548

[60] Katerelos, I. and Varotsis, N. (2017) A Cusp Catastrophe Model of Tax Behavior. Nonlinear Dynamics, Psychology, and Life Sciences, 21, 89-112.

[61] Latham, G.P. (2007) Work Motivation: History, Theory, Research, and Practice. Sage Publications, Inc., Thousand Oaks.

[62] James, L.R., LeBreton, J.M., Mitchell, T.R., Smith, D.R., DeSimone, J.A., Cookson, R. and Lee, H.J. (2013) Use of Conditional Reasoning to Measure the Power Motive. 
In: Cortina, J.M. and Landis, R.S., Eds., Modern Research Methods for the Study of Behavior in Organizations, Taylor and Francis, New York, 398-448.

[63] Ryan, R.M. and Deci, E.L. (2000) Intrinsic and Extrinsic Motivations: Classic Definitions and New Directions. Contemporary Educational Psychology, 25, 57-67. https://doi.org/10.1006/ceps.1999.1020

[64] Deci, E.L. and Ryan R.M. (1985) Intrinsic Motivation and Self-Determination in Human Behavior. Plenum Publishing Co., New York. https://doi.org/10.1007/978-1-4899-2271-7

[65] Bono, J.E. and Judge, T.A. (2003) Self-Concordance at Work: Toward Understanding the Motivational Effects of Transformational Leaders. Academy of Management Journal, 46, 554-571. https://doi.org/10.2307/30040649

[66] Deci, E.L. and Ryan, R.M. (1985) The General Orientations Scale: Self-Determination in Personality. Journal of Research in Personality, 195, 109-134. https://doi.org/10.1016/0092-6566(85)90023-6

[67] Ryan, R.M. and Deci, E.L. (2000) Self-Determination Theory and the Facilitation of Intrinsic Motivation, Social Development, and Well-Being. American Psychologist, 55, 68-78. https://doi.org/10.1037//0003-066X.55.1.68

[68] Bandura, A. (1978) Self-Efficacy: Toward a Unifying Theory of Behavioral Change. Advances in Behavior Research and Therapy, 1, 139-161. https://doi.org/10.1016/0146-6402(78)90002-4

[69] Bandura, A. (1978) Reflections on Self-Efficacy. Advances in Behavior Research and Therapy, 1, 237-269. https://doi.org/10.1016/0146-6402(78)90012-7

[70] Bandura, A. (1982) The Assessment and Predictive Generality of Self-Percepts of Efficacy. Journal of Behavior Therapy and Experimental Psychiatry, 13, 195-199. https://doi.org/10.1016/0005-7916(82)90004-0

[71] Judge, T.A., Jackson, C.L., Shaw, J.C., Scott, B.A. and Rich, B.L. (2007) Self-Efficacy and Work-Related Performance: The Integral Role of Individual Differences. Journal of Applied Psychology, 92, 107-127. https://doi.org/10.1037/0021-9010.92.1.107

[72] Bandura, A. (1997) Self-Efficacy: The Exercise of Control. Freeman, New York.

[73] Benight, C.C. and Bandura, A. (2004) Social Cognitive Theory of Posttraumatic Recovery: The Role of Perceived Self-Efficacy. Behavior Research Therapy, 421, 1129-1148. https://doi.org/10.1016/j.brat.2003.08.008

[74] Hackman, R.J. and Oldham, G.R. (1976) Motivation through the Design of Work: Test of a Theory. Organizational Behavior and Human Performance, 16, 250-279. https://doi.org/10.1016/0030-5073(76)90016-7

[75] Hackman, R.J. and Oldham, G.R. (1980) Work Redesign. Pearson Education, London.

[76] Kulik, C.T., Oldham, G.R. and Hackman, R.J. (1987) Work Design as an Approach to Person-Environment Fit. Journal of Vocational Behavior, 31, 278-296. https://doi.org/10.1016/0001-8791(87)90044-3

[77] Thaler, R.H. and Sunstein, C.R. (2008) Nudge: Improving Decisions about Health, Wealth, and Happiness. Yale University Press, New Haven, 487-493.

[78] Thaler, R.H. (2015) Misbehaving-The Making of Behavioral Economics. W.W. Norton, New York.

[79] Sunstein, C.R. (2015) Nudging and Choice Architecture: Ethical Considerations. Yale Journal on Regulation.

[80] Kahneman, D. (2011) Thinking, Fast and Slow. Farar, Straus and Giroux, New 
York.

[81] Wilk, J. (1999) Mind, Nature and the Emerging Science of Change: An Introduction to Meta-Morphology. In: Cornelis, G., Smets, S. and Van Bendegem, J., Eds., Einstein Meets Magritte: An Interdisciplinary Reflection on Science, Nature, Art, Human Action and Society: Meta-Debates on Science, Vol. 6, Springer, Berlin, 71-87. https://doi.org/10.1007/978-94-017-2245-2 6

[82] Parkinson, J.A., Eccles, K.E. and Goodman, A. (2014) Positive Impact by Design: The Wales Centre for Behaviour Change. The Journal of Positive Psychology, 9 , 517-522. https://doi.org/10.1080/17439760.2014.936965

[83] Ebert, P. and Freibichler, W. (2017) Nudge Management: Applying Behavioural Science to Increase Knowledge Worker Productivity. Journal of Organization Design, 6, 4. https://doi.org/10.1186/s41469-017-0014-1

[84] Lepenies, R. and Malecka, M. (2015) The Institutional Consequences of Nudging-Nudges, Politics, and the Law. Review of Philosophy and Psychology, 6, 427-437. https://doi.org/10.1007/s13164-015-0243-6

[85] Greek Tax Code (2010) Enhance Transparency with Mandatory Law Enforcement. Law, FEK A112/2010. The National Printing House, Athens.

[86] Kanfer, R. (1990) Motivation Theory and Industrial/Organizational Psychology. In: Dunnette, M.D. and Hough, L., Eds., Handbook of Industrial and Organizational Psychology. Theory in Industrial and Organizational Psychology, Consulting Psychologists Press, Palo Alto, 75-170.

[87] Lodge, M. and Hood, C. (2012) What Should We Do about Motivation Theory? Six Recommendations for the Twenty-First Century. Academy of Management Review, 29, 388-403. https://doi.org/10.5465/amr.2004.13670974

[88] Tzannatos, Z. and Monogios, Y. (2013) Public Sector Adjustment amidst Structural Adjustment in Greece: Subordinate, Spasmodic and Sporadic. In: Vaughan-Whitehead, D. and Edward, E., Eds., Public Sector Shock: The Impact of Policy Retrenchment in Europe, International Labour Office, Genève, 259-299. https://doi.org/10.4337/9781781955352.00012

[89] Gruening, G. (2001) Origin and Theoretical Basis of New Public Management. International Public Management Journal, 4, 1-25. https://doi.org/10.1016/S1096-7494(01)00041-1

[90] Greek Tax Code (2017) Determination of Job Description Skills of I.A.P.R. Law, FEK B 4227/2017. The National Printing House, Athens. 